\title{
Passwords
}

Volume 12 | Issue 2

Article 15

6-4-2012

\section{Stick Your Head In Gravy (1995, Autumn)}

Olivia Weissblum

ogw02010@mymail.pomona.edu

Follow this and additional works at: http://scholarship.claremont.edu/passwords

Part of the Creative Writing Commons

\section{Recommended Citation}

Weissblum, Olivia (2012) "Stick Your Head In Gravy (1995, Autumn)," Passwords: Vol. 12: Iss. 2, Article 15. DOI: 10.5642/ passwrd.20121202.15

Available at: http://scholarship.claremont.edu/passwords/vol12/iss2/15

This Story is brought to you for free and open access by the Journals at Claremont at Scholarship @ Claremont. It has been accepted for inclusion in

Passwords by an authorized administrator of Scholarship @ Claremont. For more information, please contact scholarship@cuc.claremont.edu. 


\section{Stick Your Head In Gravy (1995, Autumn) \\ Olivia Weissblum}

I'm still cute with my hair pulled back in a frizzy halo, white wool and jeans and little sneakers. I climb up on top of the bookshelf to show off and feel deeply ashamed when someone figures me out. I decide not to talk for the rest of the day.

I cried in the morning when they dropped me off, although I'm no longer sure why. When they take us to see the animals, I cling to my snotty tissue, trying to keep the tears running as long as I can stand. It's a struggle not to giggle and sacrifice self-pity when a sheep eats the nasty rag right out of my hands.

The turkey is a formidable beast, its proud chest puffed and its ugly head jutting with dumb curiosity as it waddles my way. Don't Stick Your Finger In The Turkey Cage, Megan! The teacher reprimands my friend, and I know right away that I have to do it. I tentatively poke a tender finger toward the fat bird. It pecks, as is its nature, and I cry, as is mine. 